\title{
Measuring Poverty in Malaysia: Applications of Distributive-Sensitive Poverty Indices
}

\author{
A. H. ROSLAN \\ Faculty of Economics \\ Universiti Utara Malaysia
}

\begin{abstract}
This paper represents an attempt to seek a better way to measure poverty in Malaysia. Many studies, including government published figures employ the head-count ratio as the index of poverty. However, this measure is a narrow measure of poverty. Specifically, it ignores the distribution of income among the poor, and hence has its limitation. Here, besides the usual simple head-count ratio $(H)$ that was reported in most previous studies as well as in government documents, better poverty measures were employed - the poverty-income gap ratio (I), Sen (S), Clark, Hemming and Ulph Index ( $\left.P^{*}\right)$, and Foster, Greer and Thorbecke (FGT) indices of poverty. These indices introduce a welfare function that is sensitive to the distribution of income among the poor. Thus, they provide a richer picture of the nature of poverty and thus could be used for policy design with a greater level of confidence. Furthermore, the FGT index of poverty was decomposed to examine the contribution of different groups to total poverty. These indices were calculated using the Malaysian Family Life Survey (MFLS) data.
\end{abstract}

\begin{abstract}
ABSTRAK
Kertas ini cuba mengemukakan indek yang lebih baik bagi mengukur kemiskinan di Malaysia. Kebanyakan kajian, termasuk data daripada dokumen rasmi kerajaan menggunakan indek kadar kemiskinan sebagai indek mengukur tingkat kemiskinan. Bagaimanapun, ukuran ini mempunyai kelemahan kerana indek ini mengabaikan agihan pendapatan di kalangan mereka yang miskin. Dalam kajian ini, selain daripada indek kadar kemiskinan yang dilaporkan dalam kajian lepas dan juga dokumen rasmi kerajaan, indek kemiskinan yang lebih baik iaitu nisbah jurang pendapatan-kemiskinan (I), indek Sen (S), indek Clark, Hemming dan Ulph ( $\left.P^{*}\right)$, dan indek Foster, Greer dan Thorbecke (FGT) digunakan. Indek-indek ini mengambil kira fungsi kebajikan yang sensitif kepada agihan pendapatan di kalangan isi rumah miskin. Oleh yang demikian, indek-indek kemiskinan ini memberi gambaran yang lebih baik tentang kemiskinan dan lebih meyakinkan untuk digunakan dalam merangka dasar. Selain itu, indek kemiskinan FGT boleh dipecahkan untuk melihat sumbangan kemiskinan kumpulan yang berbeza kepada jumlah indek kemiskinan. Indek-indek kemiskinan ini dikira menggunakan data daripada Malaysian Family Life Survey (MFLS).
\end{abstract}

\section{INTRODUCTION}

Poverty alleviation is one of the main objectives of the development policy in Malaysia. Thus it is desirable to know the exact extent of poverty as well as to know whether measures taken to re- duce poverty (really) have an impact. In this regard, measures used to calculate poverty are imperative. The most commonly used measures of poverty in government documents are the headcount ratio. These measures have shortcomings for gauging poverty for example Fields (1994), 
Sen (1997b), and Zheng (1997). This study employs a set of better indices of poverty - the poverty-income gap index (I), the Sen index (S), Clarke, the Hemming and $\mathrm{Chu}\left(\mathrm{P}^{*}\right)$ index, as well as the Foster, Greer and Thorbecke (FGT) index. ${ }^{1}$ Except for the poverty-income gap index (I), all of these indices introduce a welfare function that is sensitive to the distribution of income among the poor. Hence, they provide a richer picture of the nature of poverty. Furthermore, the FGT index of poverty could be decomposed to examine the contribution of different groups to total poverty. The data used in this study is the Malaysian Family Life Survey (MFLS) data set.

The objective of this study is to calculate poverty in Malaysia using theoretically better measures of poverty. Thus, this study highlights better measures of poverty than the most commonly used head-count ratio $(\mathrm{H})$ to policy makers and researchers. Furthermore, by using alternatively better measures of poverty and also a different data set, the findings of this study could be used to verify the poverty figures that have been reported in previous studies and government documents. In this regard, the scientific contribution of the research would be the application of more attractive measures of poverty that could be used for policy design with a reasonable level of confidence.

This paper is organised into five subsections. Following this introduction, the following Section II provides the description of the data. Section III examines income inequality of the overall, rural-urban, and each ethnic group, as well as the contribution of between-group and withingroup inequality to total inequality. Section IV analysis the extent of poverty. Section V summarises as well as concludes the paper.

\section{DATA}

The present study employs household income data from the Malaysian Family Life Survey (MFLS), which was conducted in Peninsular Malaysia by the RAND Corporation, USA. There are two surveys - the MFLS1 and the MFLS2. The MFLS1 was fielded in 1976-1977, while the MFLS2 was fielded in 1988-89 as a follow-up survey to the MFLS1. ${ }^{2}$ The information gathered in both surveys seems not only suitable for demographic related studies such as fertility, family planning, marriage and migration as the surveys intended, but also appropriate for studies on income distribution and poverty since information on income and wealth was also collected. Indeed, researchers in their study of poverty and income distribution in Malaysia have used the MFLS data. ${ }^{3}$ Thus, the MFLS data could provide reliable and useful information on the poverty and income distribution in Malaysia.

Both MFLS1 and MFLS2 samples were selected from a sampling frame designed by the Malaysian Department of Statistics. The household samples include only households with at least one ever-married woman aged 50 years or younger, that is, one who had been married at least once, regardless of her present marital status. The relevant data used in the analysis is taken from the following questionnaires of the MFLS1: MF1 (Household Roster), MF4 (Female Time Budget), MF5 (Male Time Budget), and MF6 (Income and Wealth). On the other hand, the data from the MFLS2 is taken from these questionnaires: MF25 (Household Economy), MF21 (Household Roster), and MF26EB and MF27COMM (Community Level Data). There are a total of 1263 and 1512 households in the MFLS1 and MFLS2 samples, respectively. Households with incomplete data are omitted. The number of household samples left for analysis in the study totals 1245 for MFLS1 and 1507 for MFLS2.

The MFLS gathered information generally on all income received by the households cash and non-cash income, which included the value of self-activities such as household products and services for own consumption. Income data was collected on agricultural production, ownership of animals, businesses owned, services performed, gifts from non-household members, inheritance or dowries received, income from insurance, pensions, retirement programs and interest; income received from renting rooms, houses or land; ownership of land; and possession of durable goods. Thus, the concept of income used in the MFLS was fairly broad. 


\section{MEASURES OF POVERTY}

Poverty assessment is basically a two-step process (Sen 1997). The first step involves the identification of the poor among the population, and the second step is to gather the relevant data of the poor, which is essentially getting an aggregate poverty index of the population. The most common approach to identify the poor is by defining the income poverty line, that is, the borderline income that separates the poor from the nonpoor. Thus, those incomes that fall below the poverty line are considered to be those of the poor. While this approach seems simple, it actually involves complex and difficult conceptual issues. The problem arises in determining the appropriate poverty line. As there are different perceptions on poverty, therefore there are various suggestions as well as disagreements on how to define the poverty line.

Basically there are two approaches to define the poverty line: (i) the absolute approach and (ii) the relative approach. The absolute approach defines the poverty line that is independent of the standard of living of the general population. This approach involves a concept of a minimum standard of living, that is, the minimum level of consumption (for instance nutritional requirement) for survival. Thus, the poverty line is the estimated cost of the bundle of goods necessary to ensure that the basic minimum requirements are met. The difficulty, however, is to identify what these minimum requirements are. Usually this refers to physical requirements for survival, for example, nutritional requirements. Thus, one of the most important components of basic requirements is food expenditure, which is usually based on food energy intake level. In addition, a certain amount of non-food items such as housing and clothing is also included.

The relative approach, however, defines the poverty line in relation to the general standard of living that prevails in the society. This approach defines a person as being poor when his or her income is significantly below the national average. One relative measure defines poverty as the situation at the lower end of the income distribution scale, for example; the bottom 10 or 20 percent. However, using this definition, poverty will only be diminished if complete equality of income is achieved, since the bottom 10 or 20 percent will always exist whenever income is not equally distributed. Besides, this relative approach to poverty is also likely to give no indication of the quality of life of the poor.

With regard to the poverty line in Malaysia, it is surprising to find that income poverty lines were not officially published until the publication of the Mid-Term Review of the Fifth Malaysia Plan in 1989, where the official income poverty line in 1987 as mentioned in the Mid-Term Review of the Fifth Malaysia Plan was RM350 for a household of 5.14 persons in Peninsular Malaysia (Shireen, 1998). This is quite surprising since poverty eradication is one of the main objectives of the NEP, and poverty incidence has been reported in various government official documents long before. Shireen (1998), however, has taken the trouble to estimate the income poverty line from 1978 to $1990 .{ }^{4}$ Shireen (1998) claimed that her estimation is "very close to those given by the EPU" and is fairly correct. In this study, the income poverty line estimated by Shireen (1998) is employed, which is RM252.36 for a 5.4 member household in 1977 and RM366.02 for a 5.14 member household in 1989 . While this could be a source of disagreement, it is nonetheless sufficient for the purpose of the present study.

Once the income poverty line has been determined, the next step is to determine how much poverty exists with reference to it. There are many indices of poverty proposed in the literature. The most commonly used poverty index is the head-count ratio $(\mathrm{H})$. Other indices of poverty include the poverty income gap (I), Sen (S), Clark, Hemming and Ulph ( $\left.\mathrm{P}^{*}\right)$, and Foster, Greer and Thorbecke (FGT). These indices - Sen (S), Clark, Hemming and Ulph $\left(\mathrm{P}^{*}\right)$, and Foster, Greer and Thorbecke (FGT) - are among the more attractive indices of poverty that have been proposed in the literature. Each one of these indices is discussed below:

\section{Head-Count Ratio $(H)$}

One of the simplest and most widely used measures of poverty is the "head-count ratio" or poverty incidence. The head-count ratio is basically the proportion of the total population whose in- 
come falls below the specified poverty line. Thus, suppose there are $n$ households, whose income is $\mathrm{y}_{1}, \mathrm{y}_{2}, \ldots, \mathrm{y}_{\mathrm{n}}$. Let $\mathrm{z}$ be the income poverty line, and there are $\mathrm{m}$ households with income $\mathrm{y}_{1}, \mathrm{y}_{2}$, $\ldots, \mathrm{y}_{\mathrm{m}}$, that are less than (or equal to) $\mathrm{z}$, then the head count ratio $(H)$ is simply the ratio of $m$ to $n$, that is, $\mathrm{H}(\mathrm{y}, \mathrm{z})=\mathrm{m} / \mathrm{n}$.

Table 1 shows the head-count ratio, that is the poverty incidence in Peninsular Malaysia reported in the government documents. It shows that poverty incidence was remarkably reduced from 49.3 percent in 1970 to 15.0 percent in 1990 . Furthermore, the incidence of poverty amongst the rural and urban households also declined from 58.7 and 21.3 percent to 19.3 and 7.3 percent respectively. The overall incidence of poverty as well as poverty amongst the rural and urban households declined considerably further in 2000. Poverty incidence amongst all ethnic groups also showed a substantial reduction. In particular, the incidence of poverty amongst the Bumiputera was reduced substantially from 65.0 percent in 1970 to 20.8 percent in 1990 .

Table 1:

Incidence of Poverty (\%) in Peninsular Malaysia, 1970 and 1990

\begin{tabular}{cccc}
\hline & 1970 & 1990 & 2000 \\
\hline Peninsular Malaysia & 49.3 & 15.0 & 5.3 \\
Rural & 58.7 & 19.3 & 8.0 \\
Urban & 21.3 & 7.3 & 3.0 \\
& & & \\
Bumiputera & 65.0 & 20.8 & n.a. \\
Chinese & 26.0 & 5.7 & n.a. \\
Indians & 39.0 & 8.0 & n.a. \\
Others & 44.8 & 18.0 & n.a. \\
\hline
\end{tabular}

Source: (i) Malaysia (1991, 1996)

(ii) MAPEN II (2001)

However, Fields (1994), Sen (1997) and Zheng $(1997,2000)$ have argued that the headcount ratio is not a satisfactory index to show the state of poverty in a population. Basically, the head-count ratio is the proportion of the total population whose income falls below the specified poverty line. While it does give some information on the state of poverty in the population, the shortcoming of the head-count ratio as a measure of poverty is that it fails to take into account the extent to which the income falls below the poverty line. Furthermore, it also fails to take into consideration the distribution of income of those who fall below the specified poverty line. In other words, the head-count ratio ignores the "depth" as well as the "distribution" of poverty (Sen 1997). Therefore, if income is transferred from the poorest person to the least poor such that it enables the least poor to cross over the poverty line, this seems to reduce poverty in terms of the head-count ratio. However, while it reduces the head-count ratio of poverty, it could also be the case that the quality of life of the remaining poor has worsened. Thus, apart from the head-count ratio $(\mathrm{H})$, which is normally reported in government documents as well as in previous studies, there is a need for a better measure of poverty.

\section{Poverty-Income Gap Ratio (I)}

The poverty-income gap measures the sum of the shortfall in income of each of the poor from the poverty line. Thus, it measures the depth of the poor person's poverty. If the income of the $\mathrm{i}^{\text {th }}$ poor person is $\mathrm{y}_{\mathrm{i}}$, and the income poverty line is $\mathrm{z}$, then the poverty-income gap is $z-y_{i}$. If the total income unit that are poor is $m$, then the aggregate gap of all of the poor would be the summation of all individual income gaps, that is, $\mathrm{I}=\sum\left(\mathrm{z}-\mathrm{y}_{\mathrm{i}}\right), \mathrm{i}=1,2$, 
$\ldots, \mathrm{m}$. The advantage of the poverty-income gap is that it identifies the total amount of income needed to lift all the poor up to the poverty line, that is, the minimum amount of income needed to wipe out poverty. Since the above expression ignores the number of people falling below the poverty line, the poverty-income gap ratio is preferred. It is a normalised version of the poverty-income gap, to make it independent of the number of the poor (as well as the currency in which poverty income is recorded). The poverty-income gap ratio is obtained by normalising the above expression by dividing it by the factor $\mathrm{mz}$, that is, $\mathrm{I}=\sum$ (z-yi)/(mz), i=1, 2, .,m. Yet shortcomings of this index remain. The poverty-income gap ratio still ignores the distribution of income among the poor, that is, how the total income gap is divided among them. For instance, a transfer of income from the poorest household to a less poor household, but leaving the recipient household still below the poverty line would not be reflected in a change of the index. Thus, both $\mathrm{H}$ and I indices are "best seen as partial indicators of poverty" (Sen 1997,). To overcome the problem, Sen (1997) proposes a distribution sensitive of poverty measure.

\section{Sen Index $(S)$}

Sen (1997) proposed an improvement on the poverty measure by combining a measure of distribution among the poor $\left(\mathrm{G}_{\mathrm{p}}\right)$ with the head-count ratio $(\mathrm{H})$ and the poverty-income gap ratio (I). Thus, this index introduces a welfare function, which is sensitive to income distribution among the poor. The Sen index is defined as $\mathrm{S}=\mathrm{H}$ [I - (1I) $\left.\left\{1-G_{p}(m /(1+m))\right\}\right]$. For a large number of the poor, the Sen index is reduced to $\mathrm{S}=\mathrm{H}[\mathrm{I}+(1-\mathrm{I})$ $\mathrm{G}_{\mathrm{p}}$. Nonetheless, a problem with the Sen index is that a transfer from a poor household to a less poor household could decrease the index if the latter crosses the poverty income line resulting from the transfer. This property of the Sen index might be tolerable if both households were just a little bit below the poverty line and were close to each other. This might be tolerable since the transfer which contemplated to enable the less poor household to cross the poverty income line was likely to be small. However, if the household that loses out suffers significantly as a result of the transfer, the decrease of the index would be questionable.
Clark, Hemming and Ulph (1981) have suggested a partial remedy to the problem of the Sen index.

\section{Clark, Hemming and Ulph Index $\left(P^{*}\right)$}

A partial remedy to the problem of the Sen index suggested by Clark, Hemming and Ulph (1981) is to make the greater the sacrifice of the household making the transfer to enable someone to cross over the poverty line, the lesser is the amount, if there is any, of poverty reduction. Thus, if there is a transfer from a poor person to a less poor person who is near to the poverty line, such that the latter crosses the poverty line, the poverty index may be decreased. However, the poorer the person making the transfer, the lesser the power of that transfer in reducing the poverty index. An index, $\mathrm{P}^{*}$, which was suggested by Clark, Hemming and Ulph (1981) that holds such properties is defined as $\mathrm{P}^{*}=1-\left[\mathrm{H}\{(1-\mathrm{A})(1-\mathrm{I})\}^{(1-\mathrm{e})}+(1-\right.$ $\mathrm{H})^{(1 /(1-\mathrm{e}))}$, where $\mathrm{A}$ is the Atkinson index over the income distribution of those who fall below the poverty line. The Atkinson index is defined as $\mathrm{A}$ $=1-\left(\mathrm{y}_{\mathrm{e}} / \mathrm{p}\right)$, where $\mathrm{y}_{\mathrm{e}}$ and ${ }_{-\mathrm{p}}$ are the equivalent and mean income, respectively, for the poor. The equivalent income, $y_{e}$, is defined as that income which makes the utility function equal to the mean of the utility of the poor. Thus, $\left[\mathrm{y}_{\mathrm{e}}\right]^{(1-\mathrm{e})}=(1 / \mathrm{m})$ $\sum\left[\mathrm{y}_{\mathrm{i}}\right]^{(1-e)}$, summed over $\mathrm{i}=1, \ldots, \mathrm{m}$. The Atkinson index is defined for a particular utility function in these calculations: $U\left(y_{i}\right)=(1 /-)\left[y_{i}\right]^{(1-e)}$, where $\mathrm{i}=1,2, \ldots, \mathrm{m}$, that is, those below the poverty line. To ensure the concavity of the utility function, the parameter _ must be less than unity. The parameter _ is regarded as an inequality aversion parameter in the Atkinson index of inequality. It can be regarded as a poverty aversion parameter in the context of the $\mathrm{P}^{*}$ index because here what is being considered is income distribution among the poor.

\section{Foster, Greer and Thorbecke index (FGT)}

All of the above poverty indices are not decomposable in the sense that they do not necessarily establish sensible relationships between subgroup poverty and overall poverty with a view to determining how much each subgroup contributes to total poverty. Foster, Greer, and Thorbecke (1984) proposed an index, which was not only designed to overcome this shortcoming, but also general- 
ised the $\mathrm{H}$ and I poverty indices. The FGT index is defined with respect to the parameter $\_0$ as FGT $\left(\_\right)=\sum\left(\mathrm{z}-\mathrm{y}_{\mathrm{ij}}\right)-/ \mathrm{nz}^{-}$, summed over $\mathrm{i}=1, \ldots, \mathrm{m}$. For _ $=0$, the head-count ratio is obtained, that is, FGT $\left(\_\right)=H$. For _ $=1$, the FGT(_) $=$ HI where I is the poverty-income gap ratio. It becomes more interesting for ${ }_{-}=2$, where the above expression becomes FGT $\left(\_=2\right)=\mathrm{H}\left[\mathrm{I}^{2}+(1-\mathrm{I})^{2}\left(\mathrm{CV}_{\mathrm{m}}\right)^{2}\right]$, where $\mathrm{CV}_{\mathrm{m}}$ is the coefficient of variation of the income of those who fall below the poverty line, which is defined as $\left(\mathrm{CV}_{\mathrm{m}}\right)^{2}=\sum\left({ }_{-\mathrm{m}}-\mathrm{y}_{\mathrm{i}}\right)^{2} /\left(_{-\mathrm{m}}\right)^{2}$. Here, ${ }_{-\mathrm{m}}$ is the mean value of the income of the poor, and $y_{i}$, $\mathrm{i}=1,2, \ldots \mathrm{m}$, is the income of the $\mathrm{i}^{\text {th }}$ individual among the poor.

Thus, as can be seen above, for $\_=2$, the FGT(_) index has taken into account the income distribution among the poor. To see how decomposing the FGT(_) poverty index could be done, suppose that there are k mutually exclusive and exhaustive subgroups of the sample population. Group $j$ contains $n_{j}$ number of individuals, and the sum of $n_{j}$ for $j=1, \ldots, k$ is equal to $n$, the total population. Not all individuals in any subgroup may have an income below the poverty line, which is $z$. They are only $m_{j}$ number of poor individuals in group $j$. Thus the sum of $m_{j}$ for $j=1, \ldots k$ is equal to $\mathrm{m}$, the total number of the poor individuals in the sample. For those who fall below the poverty line it will be FGT(_) $=\sum\left(n_{j} / n\right)$ FGT $_{j}\left(\_\right)$. The FGT index for subgroup $\mathrm{j}$ of the above equation is given by $\mathrm{FGT}_{\mathrm{j}}\left(\_\right)=\left[\sum\left(\mathrm{z}-\mathrm{y}_{\mathrm{ij}}\right)\right] /\left[\mathrm{n}_{\mathrm{j}} \mathrm{z}-\right]$, summed over the counter $\mathrm{j}=1,2, \ldots, \mathrm{k}$, where $\mathrm{y}_{\mathrm{ij}}$ is the income of the $\mathrm{i}^{\text {th }}$ person whose income is below $\mathrm{z}$ in the $\mathrm{j}^{\text {th }}$ subgroup. The percentage contribution to the total poverty index of the $\mathrm{j}^{\text {th }}$ group is then given by $\left[\left(\mathrm{n}_{\mathrm{j}} / \mathrm{n}\right) \mathrm{FGT}_{\mathrm{j}}\left({ }_{-}\right)\right] /$FGT(_) $* 100$. The above measures - Sen (S), Clark, Hemming and Ulph $\left(\mathrm{P}^{*}\right)$, and Foster, Greer and Thorbecke (FGT) provide a more attractive and reliable index of poverty that could be used for policy design with a greater level of confidence.

\section{FINDINGS}

Table 2 reports a set of poverty indices for 1976/ 77 and 1988/89, calculated from the MFLS data. All of them indicate that poverty declined over the period under study. The poverty incidence $(\mathrm{H})$, that is, the fraction of total households living below the poverty line declined significantly from 45 percent in 1976/77 to 22 percent in 1988/89. The results also show that not only did the proportion of the total households who lived in poverty decline, but the depth or severity of poverty also improved as reflected by the decline in the poverty gap ratio (I) from 0.48 in $1976 / 77$ to 0.35 in 1988/89. Furthermore, the distribution of income among the poor also improved as reflected by the decline in poverty indices of $\mathrm{S}, \mathrm{P}^{*}$ as well as FGT $(\alpha=2)$.

Table 2:

MFLS Data: Poverty Indices, 1976/77 and 1988/89

\begin{tabular}{ccccccccccc}
\hline & $\mathrm{N}$ & $\mathrm{m}$ & $\mu_{\mathrm{p}}$ & $\mathrm{G}_{\mathrm{p}}$ & $\mathrm{H}$ & $\mathrm{I}$ & $\mathrm{S}$ & $\begin{array}{c}\mathrm{P}^{*} \\
(\varepsilon=0.25)^{\mathrm{a}}\end{array}$ & $\begin{array}{c}\mathrm{P}^{*} \\
(\varepsilon=0.75)^{\mathrm{a}}\end{array}$ & $\begin{array}{c}\mathrm{FGT} \\
(\alpha=2)\end{array}$ \\
\hline $1976 / 77$ & 1245 & 561 & 292 & $\begin{array}{c}0.3210 \\
0\end{array}$ & $\begin{array}{c}0.4506 \\
6\end{array}$ & $\begin{array}{c}0.4792 \\
2\end{array}$ & $\begin{array}{c}0.2916 \\
6\end{array}$ & 0.2417 & 0.3060 & 0.1415 \\
$1988 / 89$ & 1507 & 337 & 556 & $\begin{array}{c}0.2060 \\
0\end{array}$ & $\begin{array}{c}0.2236 \\
6\end{array}$ & $\begin{array}{c}0.3494 \\
4\end{array}$ & $\begin{array}{c}0.1084 \\
4\end{array}$ & 0.0868 & 0.1016 & 0.0399 \\
\hline
\end{tabular}

Note: $n=$ number of households; $m=$ number of poor households; $\mu$ mean income of poor households; $\mathrm{G}_{\mathrm{p}}=\mathrm{Gini}$ coefficient of poor households; $\mathrm{H}=$ head-count ratio; $\mathrm{I}=$ poverty income-gap ratio; $\mathrm{S}=\mathrm{Sen}$ index; $\mathrm{P}^{*}=\mathrm{Clark}$, Hemming and Chu ratio; FGT = Foster, Greer and Thorbecke index.

${ }^{a}$ The symbol e stands for a poverty aversion parameter. 
Poverty also declined across all ethnic groups as well as across location (see Table 3 and Table 4). In fact, further examination of rural and urban poverty by ethnic groups also indicates a similar finding - poverty declined (see Table 5 and Table $6)$.

Table 3:

MFLS Data: Poverty Indices by Area, 1976/77 and 1988/89

\begin{tabular}{crccccccccc}
\hline & $\mathrm{n}$ & $\mathrm{m}$ & $\mu_{\mathrm{p}}$ & $\mathrm{G}_{\mathrm{p}}$ & $\mathrm{H}$ & $\mathrm{I}$ & $\mathrm{S}$ & $\begin{array}{c}\mathrm{P}^{*} \\
(\varepsilon=0.25)^{\mathrm{a}}\end{array}$ & $\begin{array}{c}\mathrm{P}^{*} \\
(\varepsilon=0.75)^{\mathrm{a}}\end{array}$ & $\begin{array}{c}\mathrm{FGT} \\
(\alpha=2)\end{array}$ \\
\hline $1976 / 77$ & & & & & & & & & & \\
Rural & 722 & 403 & 284 & 0.3266 & 0.5582 & 0.4942 & 0.3685 & 0.3053 & 0.3746 & 0.1821 \\
Urban & 523 & 158 & 314 & 0.3011 & 0.3021 & 0.4411 & 0.1848 & 0.1516 & 0.2022 & 0.0853 \\
Total & 1245 & 561 & 292 & 0.3210 & 0.4506 & 0.4792 & 0.2916 & 0.2417 & 0.3060 & 0.1415 \\
& & & & 0 & 6 & 2 & 6 & & & \\
& & & & & & & & & & \\
$1988 / 89$ & & & & & & & & & & \\
Rural & 965 & 271 & 545 & 0.2161 & 0.2808 & 0.3625 & 0.1410 & 0.1129 & 0.1323 & 0.0534 \\
Urban & 542 & 66 & 602 & 0.1600 & 0.1218 & 0.2956 & 0.0508 & 0.0399 & 0.0450 & 0.0157 \\
Total & 1507 & 337 & 556 & 0.2060 & 0.2236 & 0.3494 & 0.1084 & 0.0868 & 0.1016 & 0.0399 \\
& & & & 0 & 6 & 4 & 4 & & & \\
\hline
\end{tabular}

Note: $\mathrm{n}=$ number of households; $\mathrm{m}=$ number of poor households; $\mu_{\mathrm{p}=}$ mean income of poor households; $\mathrm{G}_{\mathrm{p}}=$ Gini coefficient of poor households; $\mathrm{H}=$ head-count ratio; $\mathrm{I}=$ poverty income-gap ratio; $\mathrm{S}=\mathrm{Sen}$ index; $\mathrm{P}^{*}=$ = Clark, Hemming and Chu ratio; FGT $=$ Foster, Greer and Thorbecke index.

${ }^{a}$ The symbol e stands for a poverty aversion parameter

Table 4:

MFLS Data: Poverty Indices by Ethnic Groups, 1976/77 and 1988/89

\begin{tabular}{lrrrccccccc}
\hline & $\mathrm{n}$ & $\mathrm{m}$ & $\mu_{\mathrm{p}}$ & $\mathrm{G}_{\mathrm{p}}$ & $\mathrm{H}$ & $\mathrm{I}$ & $\mathrm{S}$ & $\begin{array}{c}\mathrm{P}^{*} \\
(\varepsilon=0.25)^{\mathrm{a}}\end{array}$ & $\begin{array}{c}\mathrm{P}^{*} \\
(\varepsilon=0.75)^{\mathrm{a}}\end{array}$ & $\begin{array}{c}\mathrm{FGT} \\
(\alpha=2)\end{array}$ \\
\hline $1976 / 77$ & & & & & & & & & & \\
Malay & 591 & 343 & 267 & 0.3393 & 0.5804 & 0.5232 & 0.3981 & 0.3347 & 0.4060 & 0.2046 \\
Chinese & 496 & 150 & 308 & 0.3194 & 0.3024 & 0.4504 & 0.1900 & 0.1563 & 0.2154 & 0.0904 \\
Indian & 147 & 61 & 394 & 0.1595 & 0.4150 & 0.2969 & 0.1737 & 0.1343 & 0.1463 & 0.0534 \\
Total & 1234 & 554 & 293 & 0.3207 & 0.4489 & 0.4786 & 0.2902 & 0.2405 & 0.3044 & 0.1407 \\
& & & & & & & & & & \\
1988/89 & & & & & & & & & & \\
Malay & 911 & 271 & 554 & 0.2086 & 0.2975 & 0.3525 & 0.1456 & 0.1161 & 0.1348 & 0.0538 \\
Chinese & 399 & 44 & 592 & 0.1762 & 0.1103 & 0.3081 & 0.0488 & 0.0379 & 0.0438 & 0.0160 \\
Indian & 184 & 19 & 510 & 0.2334 & 0.1033 & 0.4031 & 0.0584 & 0.0468 & 0.0574 & 0.0232 \\
Total & 1494 & 334 & 556 & 0.2067 & 0.2236 & 0.3495 & 0.1085 & 0.0869 & 0.1017 & 0.0400 \\
\hline
\end{tabular}

Note: $n=$ number of households; $m=$ number of poor households; $\mu_{\mathrm{p}=}$ mean income of poor households; $\mathrm{G}=$ Gini coefficient of poor households; $\mathrm{H}=$ head-count ratio; $\mathrm{I}=$ poverty income-gap ratio; $\mathrm{S}=\mathrm{Sen}$ index; $\mathrm{P} *=\mathrm{p}$ Clark, Hemming and Chu ratio; FGT $=$ Foster, Greer and Thorbecke index.

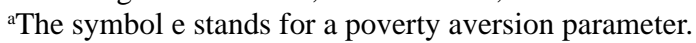


Table 5:

MFLS Data: Poverty Indices Amongst Rural Households by Ethnic Groups, 1976/77 and 1988/89

\begin{tabular}{lrrcccccccc}
\hline & $\mathrm{n}$ & $\mathrm{m}$ & $\mu_{\mathrm{p}}$ & $\mathrm{G}_{\mathrm{p}}$ & $\mathrm{H}$ & $\mathrm{I}$ & $\mathrm{S}$ & $\begin{array}{c}\mathrm{P}^{*} \\
(\varepsilon=0.25)^{\mathrm{a}}\end{array}$ & $\begin{array}{c}\mathrm{P}^{*} \\
(\varepsilon=0.75)^{\mathrm{a}}\end{array}$ & $\begin{array}{c}\mathrm{FGT} \\
(\alpha=2)\end{array}$ \\
\hline 1976/77 & & & & & & & & & & \\
Malay & 435 & 284 & 257 & 0.3546 & 0.6529 & 0.5418 & 0.4605 & 0.3874 & 0.4623 & 0.2438 \\
Chinese & 201 & 77 & 339 & 0.2468 & 0.3831 & 0.3961 & 0.2111 & 0.1707 & 0.2223 & 0.0882 \\
Indian & 76 & 36 & 381 & 0.1782 & 0.4737 & 0.3211 & 0.2166 & 0.1656 & 0.1823 & 0.0710 \\
TOTAL & 712 & 397 & 284 & 0.3258 & 0.5576 & 0.4935 & 0.3677 & 0.3045 & 0.3732 & 0.1814 \\
& & & & & & & & & & \\
1988/89 & & & & & & & & & & \\
Malay & 688 & 227 & 542 & 0.2187 & 0.3299 & 0.3656 & 0.1671 & 0.1335 & 0.1558 & 0.0637 \\
Chinese & 182 & 30 & 585 & 0.1867 & 0.1648 & 0.3156 & 0.0760 & 0.0578 & 0.0663 & 0.0251 \\
Indian & 86 & 11 & 484 & 0.2441 & 0.1279 & 0.4339 & 0.0777 & 0.0623 & 0.0770 & 0.0319 \\
TOTAL & 956 & 268 & 545 & 0.2171 & 0.2803 & 0.3628 & 0.1410 & 0.1129 & 0.1323 & 0.0535 \\
\hline
\end{tabular}

Note: $n=$ number of households; $m=$ number of poor households; $\mu_{p=}$ mean income of poor households; $G_{p}=$ Gini coefficient of poor households; $\mathrm{H}=$ head-count ratio; $\mathrm{I}=$ poverty income-gap ratio; $\mathrm{S}=$ Sen index; $\mathrm{P}^{*}={ }^{\mathrm{p}}$ Clark, Hemming and Chu ratio; FGT $=$ Foster, Greer and Thorbecke index.

${ }^{a}$ The symbol e stands for a poverty aversion parameter.

Table 6:

MFLS Data: Poverty Indices Amongst Urban Households by Ethnic Groups, 1976/77 and 1988/89

\begin{tabular}{|c|c|c|c|c|c|c|c|c|c|c|}
\hline & $\mathrm{n}$ & $\mathrm{m}$ & $\mu_{\mathrm{p}}$ & $\mathrm{G}_{\mathrm{p}}$ & $\mathrm{H}$ & I & $S$ & $\begin{array}{c}\mathrm{P}^{*} \\
(\varepsilon=0.25)^{\mathrm{a}}\end{array}$ & $\begin{array}{c}\mathrm{P}^{*} \\
(\varepsilon=0.75)^{\mathrm{a}}\end{array}$ & $\begin{array}{l}\text { FGT } \\
(\alpha=2)\end{array}$ \\
\hline \multicolumn{11}{|l|}{ 1976/77 } \\
\hline Malay & 156 & 59 & 318 & $\begin{array}{c}0.2505 \\
5\end{array}$ & $\begin{array}{c}0.3782 \\
2\end{array}$ & $\begin{array}{c}0.4340 \\
0\end{array}$ & $\begin{array}{c}0.2204 \\
4\end{array}$ & 0.1823 & 0.2259 & 0.0952 \\
\hline Chinese & 295 & 73 & 276 & $\begin{array}{c}0.3919 \\
9\end{array}$ & $\begin{array}{c}0.2475 \\
5\end{array}$ & $\begin{array}{c}0.5077 \\
7\end{array}$ & $\begin{array}{c}0.1744 \\
4\end{array}$ & 0.1464 & 0.2106 & 0.0919 \\
\hline Indian & 71 & 25 & 414 & $\begin{array}{c}0.1286 \\
6\end{array}$ & $\begin{array}{c}0.3521 \\
1\end{array}$ & $\begin{array}{c}0.2621 \\
1\end{array}$ & $\begin{array}{c}0.1344 \\
4\end{array}$ & 0.1004 & 0.1064 & 0.0345 \\
\hline TOTAL & 522 & 157 & 314 & $\begin{array}{c}0.3020 \\
0\end{array}$ & $\begin{array}{c}0.3008 \\
8\end{array}$ & $\begin{array}{c}0.4409 \\
9\end{array}$ & $\begin{array}{c}0.1841 \\
1\end{array}$ & 0.1510 & 0.2017 & 0.0851 \\
\hline \multicolumn{11}{|l|}{$1988 / 89$} \\
\hline Malay & 223 & 44 & 611 & $\begin{array}{c}0.1513 \\
3\end{array}$ & $\begin{array}{c}0.1973 \\
3\end{array}$ & $\begin{array}{c}0.2849 \\
9\end{array}$ & $\begin{array}{c}0.0802 \\
2\end{array}$ & 0.0618 & 0.0676 & 0.0233 \\
\hline Chinese & 217 & 14 & 605 & $\begin{array}{c}0.1465 \\
5\end{array}$ & $\begin{array}{c}0.0645 \\
5\end{array}$ & $\begin{array}{c}0.2920 \\
0\end{array}$ & $\begin{array}{c}0.0281 \\
1\end{array}$ & 0.0211 & 0.0245 & 0.0083 \\
\hline Indian & 98 & 8 & 547 & $\begin{array}{c}0.2115 \\
5\end{array}$ & $\begin{array}{c}0.0816 \\
6\end{array}$ & $\begin{array}{c}0.3607 \\
7\end{array}$ & $\begin{array}{c}0.0451 \\
1\end{array}$ & 0.0331 & 0.0400 & 0.0155 \\
\hline TOTAL & 538 & 66 & 602 & $\begin{array}{c}0.1600 \\
0\end{array}$ & $\begin{array}{c}0.1227 \\
7\end{array}$ & $\begin{array}{c}0.2956 \\
6\end{array}$ & $\begin{array}{c}0.0512 \\
2\end{array}$ & 0.0402 & 0.0454 & 0.0158 \\
\hline
\end{tabular}

Note: $n=$ number of households; $m=$ number of poor households; $\mu_{\mathrm{p}=}$ mean income of poor households; $\mathrm{G}_{\mathrm{p}}=$ Gini coefficient of poor households; $\mathrm{H}=$ head-count ratio; $\mathrm{I}=$ poverty income-gap ratio; $\mathrm{S}=$ Sen index; $\mathrm{P}^{*}=\mathrm{Clark}^{\mathrm{p}}$, Hemming and Chu ratio; FGT $=$ Foster, Greer and Thorbecke index.

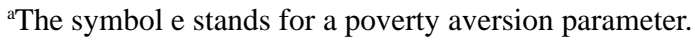


In general, there is agreement among all the poverty indices that poverty declined between $1976 / 77$ and 1988/89. This finding therefore confirms the government published figures that there was a substantial reduction in poverty. With all the distributive-sensitive poverty indices showing agreement, it can be stated with confidence that poverty really declined between the periods under study. Not only has the number of poor households declined, but the severity as well as the distributional aspects of poverty has also improved.

Since poverty indices were calculated for different population sub-groups - Malay, Chinese and Indian as well as rural and urban - it might be an interesting exercise to examine to what extent each population sub-group contributes to total poverty. Most poverty indices are not decomposable, in the sense that they do not necessarily establish sensible relationships between subgroup poverty and overall poverty with a view to determining how much each subgroup contributes to total poverty. The index proposed by Foster, Greer and Thorbecke (1984), however, addresses this problem. The FGT index allows poverty to be decomposed into its various components' contribution as was mentioned earlier.

Table 7 reports the decomposition of poverty FGT $(\mathrm{a}=2)$ by area. It shows that it is the rural household poverty that contributed the most to total poverty. Indeed between 1976/77 and $1988 / 89$, the contribution of rural household poverty to total poverty increased. Table 8 reports the decomposition of poverty FGT $(\mathrm{a}=2)$ by ethnic groups. It shows that the contribution of Malay household poverty to total poverty was similar to that of rural households.

Further investigation shows that the contribution of poverty amongst the Malays to total poverty was significantly large in both the rural and urban areas (Table 9 and Table 10). What these decomposition exercises show is that, while poverty amongst the Malay households has been substantially reduced, they still formed the largest group under poverty. Furthermore, this result also implies that while poverty amongst the Malays has significantly declined, the decline was much slower compared to that of the Chinese and the Indians.

\section{CONCLUSION}

One of the main objectives of development policy is poverty alleviation. Eliminating poverty and raising the well-being of the poor so that they could realise their full human potential is a worthy purpose in itself that needs no further explanation. For this reason, poverty reduction has been made central in Malaysia's development policy. The government has carried out various programs to lift the poor out of poverty. Thus, knowing the effectiveness of policy measures carried out to reduce poverty is essential. Nevertheless, policy evaluation with regards to the effectiveness of poverty reduction programs should not be made

Table 7:

MFLS Data: Decomposition of Poverty [FGT ( $\alpha=2)$ ] by Area, 1976/77 and 1988/89

\begin{tabular}{|c|c|c|c|c|c|c|c|c|}
\hline & $\mathrm{n}_{\mathrm{j}}$ & $\mathrm{m}_{\mathrm{j}}$ & $\mu \mathrm{m}_{\mathrm{j}}$ & $\mathrm{n}_{\mathrm{j}} / \mathrm{n}$ & $\begin{array}{l}\mathrm{FGT}_{\mathrm{j}} \\
(\alpha=2)\end{array}$ & $\begin{array}{c}{\left[\left(\mathrm{n}_{\mathrm{j}} / \mathrm{n}\right)^{*} \mathrm{FGT}_{\mathrm{j}}\right.} \\
(\alpha=2)]\end{array}$ & $\begin{array}{c}{\left[\left(\mathrm{n}_{\mathrm{j}} / \mathrm{n}\right) / * \mathrm{FGTj}\right.} \\
(\alpha=2)] / \mathrm{FGT}(\alpha=2)\end{array}$ & $\begin{array}{l}\% \text { contribution } \\
\text { to poverty }\end{array}$ \\
\hline \multicolumn{9}{|l|}{ 1976/77 } \\
\hline Rural & 722 & 403 & 284 & 0.5799 & 0.1821 & 0.1056 & 0.7465 & 74.65 \\
\hline Urban & 523 & 158 & 314 & 0.4201 & 0.0853 & 0.0359 & 0.2535 & 25.35 \\
\hline Total & 1245 & 561 & 292 & 1.0000 & 0.1415 & 0.1415 & 1.0000 & 100.00 \\
\hline \multicolumn{9}{|l|}{$1988 / 89$} \\
\hline Rural & 965 & 271 & 545 & 0.6403 & 0.0534 & 0.0342 & 0.8582 & 85.82 \\
\hline Urban & 542 & 66 & 602 & 0.3597 & 0.0157 & 0.0057 & 0.1418 & 14.18 \\
\hline Total & 1507 & 337 & 556 & 1.0000 & 0.0399 & 0.0399 & 1.0000 & 100.00 \\
\hline
\end{tabular}


merely a "number crunching" exercise. As each index of poverty captures different aspects or dimensions of poverty, there is loss of information associated with each of these indices. For this reason, the choice and computation of poverty indices to estimate the level and extent of poverty are not only imperative but must be rigorous so as they reflect the depth or severity as well as the distributional aspects of poverty. This is important solely because it will enable policy makers to be sure of the effectiveness of their various poverty alleviation programs.

Table 8:

MFLS Data: Decomposition of Poverty [FGT $(\alpha=2)$ ] by Ethnic Groups, 1976/77 and 1988/89

\begin{tabular}{|c|c|c|c|c|c|c|c|c|}
\hline & $\overline{n_{j}}$ & $\mathrm{~m}_{\mathrm{j}}$ & $\mu \mathrm{m}_{\mathrm{j}}$ & $\mathrm{n}_{\mathrm{j}} / \mathrm{n}$ & $\begin{array}{l}\text { FGT }_{j} \\
(\alpha=2)\end{array}$ & $\begin{array}{c}{\left[\left(\mathrm{n}_{\mathrm{j}} / \mathrm{n}\right) * \mathrm{FGT}_{\mathrm{j}}\right.} \\
(\alpha=2)]\end{array}$ & $\begin{array}{c}{\left[\left(n_{j} / n\right) * F G T j\right.} \\
(\alpha=2)] / F G T(\alpha=2)\end{array}$ & $\begin{array}{c}\% \text { contribution } \\
\text { to poverty }\end{array}$ \\
\hline \multicolumn{9}{|l|}{$1976 / 77$} \\
\hline Malay & 591 & 343 & 267 & 0.4789 & 0.2046 & 0.0980 & 0.6965 & 69.65 \\
\hline Chinese & 496 & 150 & 308 & 0.4019 & 0.0904 & 0.0363 & 0.2583 & 25.83 \\
\hline Indian & 147 & 61 & 394 & 0.1191 & 0.0534 & 0.0064 & 0.0452 & 4.52 \\
\hline Total & 1234 & 554 & 293 & 1.0000 & 0.1407 & 0.1407 & 1.0000 & 100.00 \\
\hline \multicolumn{9}{|l|}{$1988 / 89$} \\
\hline Malay & 911 & 271 & 554 & 0.6098 & 0.0538 & 0.0328 & 0.8218 & 82.18 \\
\hline Chinese & 399 & 44 & 592 & 0.2671 & 0.0160 & 0.0043 & 0.1067 & 10.67 \\
\hline Indian & 184 & 19 & 510 & 0.1232 & 0.0232 & 0.0029 & 0.0714 & 7.14 \\
\hline Total & 1494 & 334 & 556 & 1.0000 & 0.0400 & 0.0400 & 1.0000 & 100.00 \\
\hline
\end{tabular}

Table 9:

MFLS Data: Decomposition of Rural Household Poverty [FGT $(\alpha=2)$ ] by Ethnic Groups, 1976/77 and 1988/89

\begin{tabular}{lrrcccccc}
\hline & $\mathrm{n}_{\mathrm{j}}$ & $\mathrm{m}_{\mathrm{j}}$ & $\mu_{\mathrm{j}}$ & $\mathrm{n}_{\mathrm{j}} / \mathrm{n}$ & $\begin{array}{c}\mathrm{FGT}_{\mathrm{j}} \\
(\alpha=2)\end{array}$ & $\begin{array}{c}{\left[\left(\mathrm{n}_{\mathrm{j}} / \mathrm{n}\right) * \mathrm{FGT}_{\mathrm{j}}\right.} \\
(\alpha=2)]\end{array}$ & $\begin{array}{c}{\left[\left(\mathrm{n}_{\mathrm{j}} / \mathrm{n}\right) * \mathrm{FGTj}\right.} \\
(\alpha=2)] / \mathrm{FGT}(\alpha=2)\end{array}$ & $\begin{array}{c}\text { \% contribution } \\
\text { to poverty }\end{array}$ \\
\hline 1976/77 & & & & & & & & \\
$\quad$ Malay & 435 & 284 & 257 & 0.6110 & 0.2438 & 0.1489 & 0.8210 & 82.10 \\
Chinese & 201 & 77 & 339 & 0.2823 & 0.0882 & 0.0249 & 0.1372 & 13.72 \\
Indian & 76 & 36 & 381 & 0.1067 & 0.0710 & 0.0076 & 0.0418 & 4.18 \\
Total & 712 & 397 & 284 & 1.0000 & 0.1814 & 0.1814 & 1.0000 & 100.00 \\
1988/89 & & & & & & & & \\
Malay & 688 & 227 & 542 & 0.7197 & 0.0637 & 0.0459 & 0.8571 & 85.71 \\
Chinese & 182 & 30 & 585 & 0.1904 & 0.0251 & 0.0048 & 0.0893 & 8.93 \\
Indian & 86 & 11 & 484 & 0.0900 & 0.0319 & 0.0029 & 0.0536 & 5.36 \\
Total & 956 & 268 & 545 & 1.0000 & 0.0535 & 0.0535 & 1.0000 & 100.00 \\
\hline
\end{tabular}

Poverty statistics as commonly reported in most official government documents is the head-count ratio. It is important to note that this ratio is quite a crude measure of poverty, since it was expressed as apparently simple numbers, such as "one in five children under five lives in a poor family" or "70 percent of rural households were living in poverty". These numbers could be misleading since they ignore the severity as well as the distributional aspects of poverty. However, the head-count measure of poverty is still used despite the fact that the soundness of the concepts and methodology from which the numbers are derived has been questioned in the literature. 
Table 10:

MFLS Data: Decomposition of Urban Household Poverty [FGT $(\alpha=2)$ ] by Ethnic Groups, 1976/77 and 1988/89

\begin{tabular}{lrrcccccc}
\hline & $\mathrm{n}_{\mathrm{j}}$ & $\mathrm{m}_{\mathrm{j}}$ & $\mu \mathrm{m}_{\mathrm{j}}$ & $\mathrm{n}_{\mathrm{j}} / \mathrm{n}$ & $\begin{array}{c}\mathrm{FGT}_{\mathrm{j}} \\
(\alpha=2)\end{array}$ & $\begin{array}{c}{\left[\left(\mathrm{n}_{\mathrm{j}} / \mathrm{n}\right) * \mathrm{FGT}_{\mathrm{j}}\right.} \\
(\mathrm{a}=2)]\end{array}$ & $\begin{array}{c}{\left[\left(\mathrm{n}_{\mathrm{j}} / \mathrm{n}\right) * \mathrm{FGTj}\right.} \\
(\alpha=2)] / \mathrm{FGT}(\alpha=2)\end{array}$ & $\begin{array}{c}\% \text { contribution } \\
\text { to poverty }\end{array}$ \\
\hline 1976/77 & & & & & & & & \\
$\quad$ Malay & 156 & 59 & 318 & 0.2989 & 0.0952 & 0.0285 & 0.3344 & 33.44 \\
Chinese & 295 & 73 & 276 & 0.5651 & 0.0919 & 0.0519 & 0.6104 & 61.04 \\
Indian & 71 & 25 & 414 & 0.1360 & 0.0345 & 0.0047 & 0.0552 & 5.52 \\
Total & 522 & 157 & 314 & 1.0000 & 0.0851 & 0.0851 & 1.0000 & 100.00 \\
$1988 / 89$ & & & & & & & & \\
Malay & 223 & 44 & 611 & 0.4145 & 0.0233 & 0.0097 & 0.6098 & 60.98 \\
Chinese & 217 & 14 & 605 & 0.4033 & 0.0083 & 0.0033 & 0.2115 & 21.15 \\
Indian & 98 & 8 & 547 & 0.1822 & 0.0155 & 0.0028 & 0.1787 & 17.87 \\
Total & 538 & 66 & 602 & 1.0000 & 0.0158 & 0.0158 & 1.0000 & 100.00 \\
\hline
\end{tabular}

Thus, policy makers should not be complacent if the head-count index of poverty shows a decline, since the index actually cannot capture the severity as well as the distributional aspects of poverty. In this regard, the scientific contribution of the research is to highlight more attractive measures of poverty that could be used for policy design with a greater degree of accuracy and reliability. Using the MFLS data set, this study calculated better indices of poverty suggested in the literature than the head-count ratio that is usually reported in previous studies as well as in government document.

The results of this study show that poverty incidence, i.e. the head-count ratio $(\mathrm{H})$ declined significantly. Furthermore, not only did the proportion of the total households who lived in poverty decline, but the depth or severity as well as the distributional aspects of poverty have also improved. This was reflected by the decline in all the indices - the poverty-income gap index (I), the Sen index (S), the Clarke, Hemming and Chu $\left(\mathrm{P}^{*}\right)$ index, as well as the Foster, Greer and Thorbecke (FGT) index in the period under study. With all the distributive-sensitive poverty indices showing agreement with the head-count ratio $(\mathrm{H})$, it can be stated with greater certainty that poverty really has declined in the periods under study. The findings of this study, after taking account of the severity and distributional aspects of poverty, have not only provided clear-cut evidences, but have also verified the government published figures (that indicated there has a reduction in poverty). In addition, it has also established the following: while poverty amongst the Malays has been substantially reduced, it nonetheless represents the major contributor to total poverty and the rate of decline of poverty amongst the Malays was much slower compared to that of the Chinese and the Indians.

\section{ENDNOTES}

${ }^{1}$ In their study on poverty in Malaysia, Anand (1977 , 1983) and Shireen (1998) have employed the Sen index of poverty (S) along with the headcount ratio $(\mathrm{H})$, but not the other indices employed in this study.

${ }^{2}$ The first Malaysian Family Life Survey (MFLS1) was funded by the U.S. Agency for International Development. The MFLS1 was conducted by the RAND Corporation in collaboration, initially, with the Department of Statistics of the Government of Malaysia, and subsequently, with Survey Research Malaysia Sdn. Bhd. For more information about the survey, see Butz and Da Vanzo (1978). The second Malaysian Family Life Survey (MFLS2) was a collaborative project between RAND and the National Population and Family Development Board of Malaysia, with support from the National Institute 
of Child Health and Human Development (USA) and the National Institute on Ageing (USA). For more information about the MFLS2, see Peterson (1993).

${ }^{3}$ See for instance Blau, D. M. (1986), Kusnic, M., and DaVanso, J. (1982; 1984; 1986), Vijverberg, P. W. (1987), and Schafgans M. M. A. (2000).

${ }^{4}$ Shireen (1998) derived her estimation of the income poverty line by updating annually, component by component the income poverty line estimated by Mahbob in 1976, which was RM252.36 for a household of 5.4 persons in Peninsular Malaysia.

\section{REFERENCES}

Anand, S. (1977). Aspects of poverty in Malaysia, Review of Income and Wealth, 23, 1-16.

(1983). Inequality and poverty in Malaysia: measurement and decomposition: Oxford :University Press.

Atkinson, A. B. (1987). On the measurement of poverty, Econometrica, 55 (4), 749-64.

Blau, D. M. (1986). Self-employment, earnings, and mobility in Peninsular Malaysia, World Development, 18 (7), 839-852.

Butz, W. P., \& DaVanzo, J. (1978). The Malaysian family life survey: summary Report. Santa Monica: RAND.

Clark, S., Hemming, R., \& Ulph, D. (1981). On indices for the measurement of poverty. The Economic Journal, 91, 515-26.

Fields, G. S. (1994). Data for measuring poverty and inequality changes in the developing countries. Journal of Development Economics, 44, 87-102.

Foster, J., Greer, J., \& Thorbecke, E. (1984). A class of decomposable poverty measures. Econometrica, 52, 761-766
Ikemoto, Y. (1985). Income distribution in Malaysia: 1957-80. The Developing Economies, 23 (4), 347-67.

Kusnic, M., \& DaVanso, J. (1982). Who are the poor in Malaysia? sensitivity to measurement of income, Population and Development Review, 21.211-227.

(1984). Regional income differences and the definition of income: the case of Malaysia. International Regional Science Review, 9 (1), 59-73.

(1986). Accounting for nonmarket activities in the distribution of income: an empirical investigation. Journal of Development Economics, 21, 211227.

Mahbob, Sulaiman. (1976). "Methodology for estimates of incidence of poverty, 19701990," Mimeo, Economic Planning Unit, The Prime Minister's Department, Malaysia.

Malaysia. (1991). The Second Outline Perspective Plan, 1991-2000, Kuala Lumpur: National Printing Department.

Malaysia. (1996). Seventh Malaysia Plan, 19962000, Kuala Lumpur: National Printing Department.

MAPEN II (2001). Laporan Majlis Perundingan Ekonomi Negara Kedua, Kuala Lumpur: Percetakan Nasional Malaysia Berhad.

Peterson, C. E. (1993). The second Malaysian family life survey: user's guide, Santa Monica: RAND.

Peterson, C. E., \& Campbell, N. (1993). The first Malaysian family life survey: documentation for sub files. Santa Monica: RAND.

Peterson, C. E., Sine, J., \& Wesley, D. (1993). The second Malaysian family life survey: codebook. Santa Monica: RAND. 
Schafgans, M. M. A. (2000). Gender wage differences in Malaysia: parametric and semi parametric estimation. Journal of Development Economics, 63, 351-378.

Sen, A. (1997). On economic inequality (expanded edition with a substantial annexe by James E. Foster \& Amartya Sen), Clarendon Press: Oxford.

Shireen Mardziah, Hashim. (1998). Income inequality and poverty in Malaysia, Rowman \& Littlefield Publishers, Inc.
Vijverberg, P. W. (1987). Decomposing the earnings differentials in Peninsular Malaysia. Singapore Economic Review, 32, 24 36.

Zheng, B. (1997). aggregate poverty measures, Journal of Economic Surveys, 11, 123163.

(2000). Poverty orderings. Journal of Economic Surveys. 14 (4), 427-46. 